\title{
RUSSIAN - UKRAINIAN CONFLICT REVISITED: TOWARDS REGIME CHANGE IN RUSSIA?
}

\author{
Ryszard M. M achnikowski \\ Faculty of International and Political Studies, University of Lodz \\ Lodz, Poland \\ rmachnikowski@gmail.com
}

\begin{abstract}
A bstract
The "Ukraine crisis", as it is widely known, or more correctly, Ukraine - Russia war, started in 2013 - 2014, brought potentially devastating consequences for Central and Eastern Europe security and prospective functions of NATO military alliance. Previous Russian aggression, be it in Moldova or Georgia, went unpunished fact that created an impression that Russia had a "blank card" to do whatever it wanted within its "sphere of interests" (i.e. the territory of the former Soviet Union). Fortunately for the countries of NATO's "Eastern flank" and Scandinavian neighbours of Russia, the West ultimately responded to Moscow's military actions in the east of Ukraine. Economic and financial sanctions combined with the collapse of fossil fuels price have hit Russian economy and stopped Russia's involvement in this conflict. For the first time since the dissolution of the Soviet Union, Kremlin has been paying heavy price for its geopolitical manoeuvres. In this article I claim that as a result of Russian actions in Ukraine, this country is approaching "regime change", though the form of it remains unclear. The West should be prepared for the possible period of uncertainty in Russia, in order to minimize its possible negative consequences: period of social unrest and unknown profile and aims of future rulers of Russia.
\end{abstract}




\section{Keywords}

Conflict, crisis, regime change, Russia, sanctions, Ukraine, war

\section{RUSSIAN-KRAINIAN CONFLICT}

The history of Ukraine - Russia relations used to be complicated and consisted of ups and downs, but after Russia's military intervention in Ukraine in 2014 has reached previously unknown level of hostility. In this article I attempt to show that this "crisis" led to the unexpected, by the Kremlin's power elites, consequences. Despite territorial gains for Russia this country was met with far reaching reprisals from the West, resulting in rapid aggravation of the economic situation in Russia. This may influence the fate of power elite in this country as it reaches its climax.

The latest stage of the longstanding Ukraine - Russian "conflict" started in late autumn of 2013. Large part of the Ukrainian society was disappointed to see that their efforts to integrate with Western Europe were rejected by the government of Mr. Yanukovych, who succumbed to the enormous Russian pressure. In the summer of 2013 Russia undertook increasingly brutal economic and psychological actions aimed at changing Ukraine's pro-European political course. Much - awaited in Ukraine deal on co-operation with the EU had been long perceived by the Kremlin elite as a Western incursion into exclusive Russian "sphere of interest" and, consequently, as an existential threat for Russia. As a result, firstly Ukraine was threatened with the trade war - first shots of which were fired on 14 August, 2013 when Russian Custom Service stopped all imports coming from Ukraine. This increasing Russian economic pressure on the Ukrainian power elite should have come as no surprise - Russian officials used to issue warnings against "crossing the red lines" addressed to the West many times in the past (Kaczmarski 2009, Van Herpen 2015). In this way, Ukrainian oligarchical ruling class found themselves between the Scylla of the proEuropean expectations of a large part of their own population, located mostly in the Western part of this country (Chornohorska 2016) and Charybdis of the increasingly "assertive" Kremlin elites ready to defend ruthlessly their interests, 
with the use of force if necessary. On the one hand, quite a huge sector of Ukrainian society simply expected their country should enter the quick path towards integration with the EU, on the other, Moscow could have not accepted this move as leading to the prospective "loss" of Ukraine to Western institutions. In case of Ukraine, its rapprochement to the EU was perceived as at least equal danger as Georgian rapprochement to NATO - meaning loss of power and grip over these geopolitically important former Soviet republics.

President Yanukovych ultimately refused to sign an Association Agreement on co-operation with the EU, agreement that was planned to take form during the Summit of the European Union focused on Eastern Partnership on 28-29 November, 2013 in Vilnius. He was forced to follow his Kremlin patrons' orders (e. g. Pifer 2013) and by doing so he managed to disappoint strongly many Ukrainians, who also were determined to defend their dreams and aspirations. Ukrainian population has a long story of fights against their rulers, so it come as no surprise that on 21 November, 2013 Kiev's Maidan Nezalezhnosti (Independence Square) was flooded by masses of protesters, demanding first the cancellation of Yanukovych's decision and, finally, his resignation. On 30 November, 2013 events in Kiev entered their violent phase when the police forces started brutal crackdown on the demonstrators. Governmental violence was met with violence from the protesters, who attacked Berkut anti-riot police forces in reprisal (RT 2013). Since then protests spread out across Ukraine reaching the eastern parts of this country. They were countered with progovernment rallies and the establishment of the "Anti-maidan" movement, supported mainly in the East, inhabited by a huge Russian minority as well as the Russian-speaking Ukrainians, both holding pro-Russian attitudes (Interfax.ua 2013). By the mid - January 2014 Ukrainian government decided to introduce new legislation enabling it to dissolve demonstrations with the use of extensive force ad persecute the opposition (Al Jazeera 2014). This move was perceived as allowing "dictatorial powers" to the President and was considered to be a proof that Ukraine was sliding down into the Belarus-style dictatorship. On the Unity Day, 22 January, 2014 in Kiev two "Euromaidan" activists were shot dead by police (Union 2014) and a dead body of another Euromaidan activist shot by the "unknown perpetrators" was found on the outskirts of the city (Trach 2014). 
Despite this legal preparation for a massive crackdown on the Ukrainian opposition, when the tensions reached their highest point president Yanukovych decided to flee from Ukraine. He was soon followed by the Ukraine's Prime Minister Mykola Azarov and other government officials, who finally were found in Russia.

In this unexpected twist of fate, the power was literally lying in the streets of Kiev and pro-Russian forces in Ukraine abruptly lost their leaders. Kremlin must have perceived this situation as a severe threat for Russia's raison d'etat and decided to seek military solution to balance the rapidly growing "crisis" (Euronews 2014). The new government consisted of a staunch Ukrainian opposition, ready to put forward a pro-European policy that was much awaited by a large sector of Ukrainian society (BBC/2 2014). Russia's armed forces captured swiftly Crimea from within with the use of tactics which was a blatant violation of the international law of armed conflicts. So called "little green men" i.e. Russian soldiers without state distinctions appeared in the streets of Crimean towns and cities, quickly taking control of them. As we know today, quite a huge majority of senior officers in Ukraine's military willingly decided to join Russian side and were either disobeying resistance orders sent by their government or doing nothing to organize some armed defence against Russian soldiers (Polityuk, Zverev 2017). In any case, both the new government in Kiev and Western governments and public opinion seemed to be taken by a complete surprise with this show of Russian military might/power, and were unable to counter-react efficiently. In this way Russia managed to capture part of a land belonging to Ukraine, though perceived by some of Russians as their "native" zemlya (soil) (The Telegraph 2014). Russian forces promptly organized there a "referendum" on 16 March, 2014, the results of which were the basis for incorporating Crimea (RT 2014). On 18 March, 2014 the "Accession Treaty" between the "Republic of Crimea' and the Russian Federation was signed (Sputnik 2014) and on 21 March, 2014, it was finally approved by Russia's Federal Assembly. For Crimea the game was over - the speed and effectiveness of Russian actions, both military and "political" clearly shows that this kind of "scenario" has been prepared for Crimea for quite a long time. 
Hence, since the very beginning of the so called "Ukrainian crisis", Russian involvement was obvious and absolutely essential for understanding these events. As history shows, Kremlin elites had never respected the sovereign will of other nations if only it stood in opposition to their interests or plans. Russian annexation of the Crimean Peninsula was achieved almost without a single shot - there was hardly any resistance from the Ukrainian armed forces and "the World" had been left with no time to protest. What is noteworthy, the reaction of the "international community", including NATO and EU leaders, to this blatant violation of the international law was initially limited to the diplomatic condemnation and words of solidarity with the new Ukrainian government. It is worth reminding that the annexation of Crimea violated not only the so called Budapest Memorandum (signed by Ukraine, Russia and by two major NATOmembers: the U.S. and U.K.)1 but also the Partition Treaty on the Status and Conditions of the Black Sea Fleet, signed by Ukraine and Russia in May, 1997 and the 1991 Agreement Establishing the Commonwealth of Independent State. Russia not only did not cease its military action in Ukraine but was ready to extend it on the Eastern part of this country. The "destabilization" of Donbass and Luhansk regions happened very soon - "popular resistance" movement, organized by Russia, managed to capture large parts of the east of Ukraine (Rand 2017, Sutyagin 2015). Armed "militants", or "terrorists", as the new government in Kiev preferred to call them, were the local "militiamen" drafted for this occasion, including criminals - but guided, and controlled by Russian special services and special forces which supported this alleged "popular insurgency". The lands conquered by this "rebellion" were soon declared "independent" as Donetsk and Luhansk People's Republics (Wiener-Bronner 2014). But here Kremlin has not decided to copy the Crimea's "scenario" and, so far, has not incorporated these lands directly into Russian Federation. Annexation of these lands and establishment of the so called "Newrussia" could be perceived as an open grab of a large part of Ukrainian soil and would probably lead to the release of even more serious international outcry followed by another round of sanctions.

After initial absence of any Ukrainian counter-action, in April, 2014 the new government announced starting of the "antiterrorist" operation in the eastern 
part of the country. It was led by the newly created N ational Guard troops, backed by regular Army units, including artillery and airpower, and followed by western Ukraine "volunteers" drafted mostly from the Ukraine's nationalist movement. Ukrainian military forces quickly showed their upper hand over "popular militia" and started to regain pretty quickly the lost ground fact that led to a significant retreat of the "Novorossiya" forces, pushing "separatists" towards the border zone by the end of July 2014. This retreat provoked the intervention of the regular Russian military units, including armoured battalions, parachutists and heavy artillery, flooding Eastern Ukraine in August 2014 (Bidder et al. 2014). As the result, Russian troops not only regained all the land formerly seized by the "insurgents" but threatened to go further towards southern coastal city of Mariupol (Kramer and Gordon 2014). This Russian military advancement led newly elected Ukrainian president, Petro Poroshenko, to propose a permanent ceasefire agreement, which included the withdrawal of all heavy weapons on both sides and establishment of the "buffer zone" between Ukrainian military forces and pro-Russian "separatists". The Agreement called M insk protocol was signed on 5 September 2014 (OSCE 2014). The ceasefire lasted till January 2015 when heavy clashes between Ukrainian and "separatists" forces broke out around Donetsk International Airport and the city of Debaltsevo. Second ceasefire agreement called M insk II was signed in February 2015 (OSCE 2015) and since then the conflict has been "frozen", though minor clashes between opposing parties still happen and people, both soldiers, paramilitaries and civilians are still being killed there.

Russia is also accused of other forms of "destabilization" of Ukraine, namely supporting and organizing acts of terrorism, incursions of its military personnel and numerous assassinations in the Central and Western part of Ukraine which is under Kiev's governmental control (Oliphant 2017). Russian-built antiaircraft BUK missile operated by the "pro-Russian" forces (BUK - TELAR rocketlauncher was a belonging of the Russian 53 A nti-aircraft Rocket Brigade stationed in the city of Kursk) on 17 July, 2014, shot down Malaysian Boeing 777, flight MH17 what was a cause of an international outrage and confronted Western public with the real nature of the conflict in the east of Ukraine (JIT Info 2016). 
By its military involvement since the very beginning of this conflict Russia has managed to carry out the de facto partition of its neighbour. With the annexation of the Crimea and detachment of the eastern regions of Ukraine, Russia has deprived Kiev of control over a large part of its country and population. Exactly the same happened earlier to other neighbours of Russia - Georgia (so called " 5 days war" in August 2008) and the Republic of Moldova (the case of the so called "Transnistria" war 1990 - 92). This time, however, Moscow achieved results standing in huge contradiction to its expectations. Though initial diplomatic reactions from the EU, UN, USA and NATO to the ongoing "crisis" in Ukraine were rather anemic, and president Obama's administration finally took a notice that there was a growing "problem" with Russia only after the annexation of Crimea, Russia's actions in Ukraine ultimately led to imposing slow but persistent anti - Russian sanctions. The initial choir of Western academics, politicians and industrialists who were ready to talk about "caution" in assessment of the Russian involvement into ongoing military conflict and wowing for "understanding" of Kremlin motives and moves did not halt legal reaction to the Russian actions in Eastern Ukraine. Since spring 2014 Western countries and organizations gradually imposed increasingly severe economic sanctions on Russian companies, officials and individuals. They detached Russia banks from Western credit lines that apparently led to the collapse of Russian currency - ruble - and resulted in a financial crisis in Russia (Reuters 2014). Some countries, including Norway, Canada, Australia and Japan followed American and European decisions. Some sanctions were specifically targeting Crimea and complicated economic situation of this annexed region (RT/2 2014). First round of sanctions was associated with an illegal "referendum" which took place in Crimea and President Putin's recognition of this part of Ukraine as an "independent state" element which enabled its prompt annexation by Russia (White House 2014). Further sanctions followed Russia's aggressive military actions in Ukraine (International Trade Compliance Update 2014). Sanctions affected major Russian companies from the financial, energy and defence sectors as well as government officials and individuals considered to be personally involved in supporting and financing "terrorism" in Ukraine, and was met with outrage in Moscow. As a result, Russian economy gradually slowed down and 
some budgetary spending, including ambitious military programs, had to be limited (Reuters 2015, Fleischer 2015). What is more important, the developing Russia - Germany economic and political co-operation had to be halted German companies had no other choice but to limit significantly their involvement in Russia, as major contracts had been frozen (Meister 2015). Moreover, the price of fossil fuels on world's markets significantly decreased since the beginning of the "crisis" in Ukraine, fact that has severely affected Russia's budget, heavily dependent of the sale of Russian gas and oil.

Moreover, Russia's action in Ukraine effectively diverted Western policies towards this country based on the presumption that Russia had been a cooperative state and would have not threaten the post-Cold War political order in Europe and beyond. Subsequent Russian military actions in Syria proved that it should be contained through the show of military force, otherwise it could become a threat to the stability of Europe itself. As a result, many countries, particularly Russia's neighbours, including the Baltic States, Scandinavians and Romania, have initiated even closer co-operation with and within NATO to prepare for a possible Russian invasion (Witte 2014). The Baltic States felt particularly threatened as a possible military scenario repeating Ukrainian case could have been executed with ease on their territory (Borger and Harding 2014, Machnikowski 2015). Through its policy, Russia managed to reverse post - Cold War American policy based on the withdrawal of major USA troops from Europe - some military units, including armoured battalions came back to Europe and were located in NATO's "Eastern flank", including Baltic states, Poland and Romania (Batchelor 2017). USA air forces were also located closer to Russia and, together with other armed forces, were involved in military exercises to show the ability and commitment of America to defend its European allies (e. g. Cohen 2017). In June 2014, during his state visit to Poland, President Barack Obama declared the introduction of the European Reassurance Initiative (ERI) which covered the increase of the USA military presence in Europe in order to ensure the security of the European states against possible Russian aggression (BBC 2014). The direct result of ERI is the military O peration Atlantic Resolve and it includes rotational presence of an American heavy brigade and other military forces in Poland, Romania and the Baltic States. Most recently, under the aegis of 
the Operation Atlantic Resolve (US Army Europe 2017) more than 1,100 troops including 900 USA soldiers as well as 150 British and 120 Romanians were deployed in Orzysz in Northern Poland, which is close to Russia's Baltic Sea enclave of Kaliningrad. Through pretty modest military means (in comparison to the Cold War period levels) NATO attempts to contain further Russian aggressive moves and actions in its neighbourhood. Under Trump administration USA is even considering selling offensive lethal military equipment to Ukraine what might sharply increase Ukrainian military potential and boost Ukrainian's troops morale (Peterson 2017).

Through the annexation of Crimea and both direct and indirect military involvement into Ukrainian "crisis" Russia evoked Western reaction standing in deep contradiction to the previous experience, when USA and European powers decided to turn a blind eye to Russian military actions in the region of Russia's "close abroad". Previous "destabilization" of Moldova, resulted in a detachment of "Transnistria" from this country, and the open Russia's war with Georgia had not caused the West to change its attitude towards Putin's Russia (Asmus 2010). This "appeasement" type of approach might have persuaded his inner circle that the West was unable to respond boldly on Russian aggressive actions and hence they had a blank card to do whatever they find plausible - including aggression against neighbouring countries. Russian authorities probably had been pretty sure that another act of open interference in the internal affairs of its neighbour would have gone unpunished in any way. But to their surprise, this time both the USA and the EU decided to react firmly, though not promptly, to deter Russia at the borders of NATO. Despite Moscow's efforts to present itself as a military giant, Russian armed forces are still not a match to American and joint NATO forces. Hence, Russia cannot exceed the certain level of aggression in its actions. Politics by coercion has its limits but still Russia is prone to use available resources, other than military, to affect the situation in Europe. But instead of brute force, Russia prefers to use the so called "active measures" to influence foreign societies and governments (Snegovaya 2015, Kragh and Åsberg 2017). "Psychological information operations" seems to be the preferred weapon of choice used by Kremlin today as they give the Russians an option of "plausible denial" and usual 
bullying seems not to be as effective as it previously has been (Darczewska 2014, Darczewska 2016, Darczewska and Żochowski 2017).

Though it is hard to assess the effectiveness of Russian meddling with the use of "info-wars", it still tries to affect the political preferences of the Western public. This includes attempts to influence the results of elections (Sputnik 2017, Lipton, Sanger and Shane 2016) as well as creating an environment which is favourable to the development of the extreme political parties in the West. These parties may contribute to some form of "destabilization" of the political situation there and, by strange coincidence, they usually are much more pro-Russian than the political "mainstream" there (though obviously there are exemptions from this rule). Though Russia can contribute to the worsening of the situation in the West and spread unrest there due to its "hybrid" resources, it is paying a huge price for these

activities. Russian actions in Ukraine, Syria and against the Western public are major reasons for serious and longstanding deterioration of the Western - Russian relations. Despite the fact that it is much harder to prove Russia's power in cyberspace than in the real world, the U.S. has recently decided to impose new sanctions as a punishment for Russia's attempts to influence democratic procedures (Crawley 2017).

\section{CONCLUSIONS}

Through its overt and covert actions against Ukraine, Russia provoked initially slow but persistent collapse of relations both with Western Europe and the U.S. Financial sanctions which were primary reprisal tool in Western arsenal, combined with the low price of fossil fuels has caused economic crisis in this country. As ambitious military projects still consume vast part of the Russian budget, these military spending result in a decline of the living standard of ordinary Russians (Movchan 2017). Thirty years ago the predecessor of the Russian Federation, the Soviet Union, entered a very similar path - Soviet invasion of Afghanistan led also to Western economic sanctions and combined with the arms race resulted in the rapid decline of the Soviet economy. The rest of this story is already known to us. It is not a heresy to expect that the further deterioration of Russian economy may 
ultimately lead to the delegitimization of the current Russian power elites. The question remaining concerns the way the "regime change" would ultimately be realized in this country. Russia seems to approach a point the Soviet Union had reached shortly before its dissolution - the economy crumbles, living standard of ordinary people deteriorates, military spending is a growing burden for the financial situation, though still the authorities are willing to intervene abroad (Trenin 2017). Russia's intervention in Ukraine might be an equivalent of the Afghanistan disaster to the Soviets, though obviously with much lower level of fatalities among Russian soldiers there, but still harming the delicate fabric of its society. It is difficult to predict the way the transition of power can ultimately happen in this country - so let us hope when it happens it is going to be a relatively peaceful process rather than a violent one.

\section{AN NEX}

${ }^{1}$ They all signed six agreements for Ukraine, these agreements are:

1. The Russian Federation, the United Kingdom of Great Britain and Northern Ireland and the United States of America reaffirm their commitment to Ukraine, in accordance with the principles of the Final Act of the Conference on Security and Cooperation in Europe, to respect the independence and sovereignty and the existing borders of Ukraine;

2. The Russian Federation, the United Kingdom of Great Britain and Northern Ireland and the United States of America reaffirm their obligation to refrain from the threat or use of force against the territorial integrity or political independence of Ukraine, and that none of their weapons will ever be used against Ukraine except in self-defence or otherwise in accordance with the Charter of the United Nations;

3. The Russian Federation, the United Kingdom of Great Britain and Northern Ireland and the United States of America reaffirm their commitment to Ukraine, in accordance with the principles of the Final Act of the Conference on Security and Cooperation in Europe, to refrain from economic coercion designed to subordinate to their own interest the exercise by Ukraine of the rights inherent in its sovereignty and thus to secure advantages of any kind; 
4. The Russian Federation, the United Kingdom of Great Britain and Northern Ireland and the United States of America reaffirm their commitment to seek immediate United Nations Security Council action to provide assistance to Ukraine, as a non-nuclear-weapon State party to the Treaty on the Non-Proliferation of Nuclear Weapons, if Ukraine should become a victim of an act of aggression or an object of a threat of aggression in which nuclear weapons are used;

5. The Russian Federation, the United Kingdom of Great Britain and Northern Ireland and the United States of America reaffirm, in the case of Ukraine, their commitment not to use nuclear weapons against any nonnuclearweapon State party to the Treaty on the Non-Proliferation of Nuclear Weapons, except in the case of an attack on themselves, their territories or dependent territories, their armed forces, or their allies, by such a State in association or alliance with a nuclear-weapon State;

6. Ukraine, the Russian Federation, the United Kingdom of G reat Britain and $\mathbf{N}$ orthern Ireland and the United States of America will consult in the event a situation arises that raises a question concerning these commitments.

Source:https://treaties.un.org/doc/Publication/UNTS/No\%20Volume/50 069/Part/I-50069-0800000280338ba9.pdf

2 See e.g.: John Mearsheimer Why the Ukraine Crisis Is the West's Fault. The Liberal Delusions That Provoked Putin, "Foreign Affairs" September/October 2014; Niemcy: Były kanclerz Helmut Schmidt broni polityki Putina wobec Krymu, "Interia", 26 March 2014; "Die Zeit" ostrzega przed kandydatem na szefa dyplomacji.“Niech trzyma się z dala od MSZ”, "TVN24”, 2 October 2013; Niemiecki polityk: Działania Rosji skutkiem przyjęcia Polski do NATO, “Gazeta.pl”, 11 March2014; "Handelsblatt”: Krym należy do Rosji tak jak Vermont do USA, "Onet.pl", 13 March 2014; D. Heinrich, A. Wojnarowska, Niemieccy eksperci: „Demonizowanie Putina nie jest polityką, tylko alibi wobec jej braku", "Deutsche Welle", 20 March 2014; Niemcy: Eurosceptycy z AfD przeciw sankcjom wobec Rosji, "Interia”, 23 March 2014; Berlusconi broni Putina. "Niweczy się zbliżenie z Rosją", “Dziennik.pl”, 26 March 2014; Polityk Zielonych przeciwko rozlokowaniu oddziałów w Polsce. "Pobrzękiwanie szabelką", "TVN24", 3 April 2014; Impreza Schroedera z Putinem oburza prasę, ale nie Niemców. "To najbardziej przerażające", "TVN24", 30 April 2014; Schroeder dla "Die Welt": Nie izolować Putina, "Interia", 11 May 2014; Wpływowy niemiecki dziennik o natowskich , jastrzębiach" i "dolewaniu oliwy do ognia”, “TVN24", 8 
May 2014; M. Pawlak, „Tylko żadnych gestów militarnych”. Niemiecki ekspert o polityce NATO wobec Rosji, "Deutsche Welle", 23 May 2014; Francuska ultraprawica mówi głosem Rosji. Marine Le Pen popiera federalizację Ukrainy, “TVN24”, 12 April 2014; Niemiecka Lewica broni Rosji, "TVN24", 11 May 2014;

\section{REFERENCES}

- $\quad$ Al Jazeera. 2014. "Ukraine adopts tough anti-protest laws." Al Jazeera, January 17, 2014. http://www.aljazeera.com/news/europe/2014/01/ukraineadopts-tough-anti-protest-laws-2014116171328466370.html

- Asmus, Ronald. 2010. A Little War that Shook the World, Palgrave Macmillan, New York

- $\quad$ Batchelor, Tom. 2017. "The map that shows how many Nato troops are deployed along Russia's border." The Independent, February 5, 2017. http://www.independent.co.uk/news/world/europe/russia-nato-borderforces-map-where-are-they-positioned-a7562391.html

- $\quad$ BBC. 2014. "European Reassurance Initiative: Obama announces $\$ 1 \mathrm{bn}$ fund." BBC, June 3, 2014. http:/ / www.bbc.com/news/world-europe-27671691

- $\quad$ BBC/2. 2014. "EU signs pacts with Ukraine, Georgia and Moldova." BBC, June 27, 2014. http:/ / www.bbc.com/news/ world-europe-28052645

- $\quad$ Bidder, Benjamin, Gathmann, Moritz, Neef, Christian, Schepp, Matthias. 2014. “Undeclared War. Putin's Covert Invasion of Eastern Ukraine." D er Spiegel, September 2, 2014. http://www.spiegel.de/international/world/russiaexpands-war-in-eastern-ukraine-amid-web-of-lies-a-989290.html

- $\quad$ Borger, Julian, Harding Luke. 2014. "Baltic states wary as Russia takes more strident tone with neighbours." The Guardian, September 18, 2014. https://www.theguardian.com/world/2014/sep/18/baltic-states-wary-russiastrident-estonia-latvia-lithuania-nato

- Chornohorska, Anastasia. 2016. “Ukrainians overwhelmingly support European Integration." Euromaidan Press, April 1, 2016 http://euromaidanpress.com/2016/04/01/ukrainians-overwhelminglysupport-european-integration-infographics/\#arvlbdata

- $\quad$ Cohen, Zachary. 2017. "US bombers arrive in Europe as Russia preps for war games." CN N, August 24, 2017.http://edition.cnn.com/2017/08/23/politics/us-b-1-bombers-arrive-ineurope/index.html 
- Crawley, Michael. 2017. "Trump signs Russia sanctions bill he opposed." Politico, July 29, 2017.https://www.politico.eu/article/trump-signs-russiasanctions-bill-he-opposed/

Darczewska, Jolanta. 2014. "The anatomy of Russian information warfare. The Crimean operation, a case study". OSW Studies, vol. 42, OSW Warsaw.

- Darczewska, Jolanta. 2016. "Russia's armed forces on the information war front. Strategic documents", OSW Studies, vol. 57, OSW Warsaw.

- $\quad$ Darczewska, Jolanta, Żochowski, Piotr. 2017. “Active measures. Russia's key export", OSW Studies, vol. 64, OSW Warsaw.

- $\quad$ Euronews. 2014. "Full video: Putin's address on Crimea joining Russia, signing ceremony."

- Euronews,

March

14,

2014.https:/ / www.youtube.com/watch?v=Ayu3Ecdbl0Q

- Fleischer, Paweł. 2015. "Rosja tnie wydatki obronne. Program modernizacji kontynuowany."[Russia cuts the defence spending. The modernization program continues] Defence 24.pl, February 2, 2015.http:/ / www.defence24.pl/186770,rosja-tnie-wydatki-obronne-programmodernizacji-kontynuowany

- $\quad$ JIT info. 2016. "JIT: Flight MH17 was shot down by a BUK missile from a farmland near Pervomaiskyi." Openbaar Ministerie, Setember 26, 2016. https://www.om.nl/onderwerpen/mh17-crash/@96068/jit-flight-mh17shot/

- Interfax.ua. 2013. "Several thousand Regions Party activists continue rally in support of Yanukovych." Interfax, December 8, 2013.http:/ / en.interfax.com.ua/news/general/179986.html

- International Trade Compliance Update. 2014. "EU strengthens sanctions against actions undermining Ukraine's territorial integrity." ITCU, April 24, 2014.http:/ / www.internationaltradecomplianceupdate.com/2014/04/28/eustrengthens-sanctions-against-actions-undermining-ukraines-territorialintegrity /

- Kaczmarski, Marcin. 2009. „Russia's Revisionist Policy Towards the West", OSW Studies, Warsaw.http://www.osw.waw.pl/sites/default/files/prace_33.pdf

- $\quad$ Kragh, Martin, Åsberg, Sebastian. 2017. "Russia's strategy for influence through public diplomacy and active measures: the Swedish case", Journal of 
Strategic

Studies,

January

5 , 2017.http://dx.doi.org/10.1080/01402390.2016.1273830

- Kramer, Andrew Gordon, Michael. 2014 "Ukraine Reports Russian Invasion on a New Front." N ew Y ork Times, August 27, 2014.

- $\quad$ E. Lipton, D. E. Sanger and S. Shane. 2016. "The Perfect Weapon: How Russian Cyberpower Invaded the U.S." The New York Times, December 13, 2016.http://www.nytimes.com/2016/12/13/us/politics/russia-hack-electiondnc.html?hp\&action=click\&pgtype $=$ Homepage\&clickSource $=$ storyheading\&module=a-lede-package-region\&region=top-news\&WT.nav=topnews\&_r $=0$

- Machnikowski, Ryszard. 2015. „NATO and Ukraine crisis”, in: Czulda, Robert., Madej, Marek. Eds. Newcomers no more? Contemporary NATO and the Future of the Enlargment from the Perspective of the "Post-Cold War" Members, Warsaw - Prague - Brussels

- $\quad$ Meister, Stefan. 2015. "How Russia Lost Germany (and How it Can Win It Back)." Russia and Global Affairs, January/ March 2015.https://dgap.org/en/think-tank/research-programs/robert-bosch-centerfor-central-and-eastern-europe-russia-and-central

- Movchan, Andrey. 2017. “Decline, Not Collapse: The Bleak Prospects for Russia's Economy." Carnegie, February 2, 2017.http:/ / carnegie.ru/2017/02/02/ decline-not-collapse-bleak-prospects-forrussia-s-economy-pub-67865

- $\quad$ Oliphant, Roland. 2017. “Ukraine sues Russia in International Court of Justice for 'financing terrorism'." The Telegraph, March 6, 2017.http://www.telegraph.co.uk/news/2017/03/06/ukraine-suesrussia-international-court-justiceforfinancing/

- $\quad$ OSCE. 2014. “Minsk Protocol (in Russian)." OSCE Sepember 5, 2014. http:/ / www.osce.org/ru/home/123258?download=true

- $\quad$ OSCE. 2015. "Package of Measures for the Implementation of the Minsk Agreements (in Russian)." OSCE February 12, 2015.http:// www.osce.org/ru/cio/140221?download=true

- Peterson, Nolan. 2017. "Value of US Weapons Goes Far Beyond Battlefield, Ukrainian Troops Say." The Daily Signal, August 4, 2017.http:// dailysignal.com/2017/08/04/value-us-weapons-goes-far-beyondbattlefield-ukrainian-troops-say/ 
- $\quad$ Pifer, Steven. 2013. "Why Did Ukraine's Yanukovych Give in to Russian Pressure on EU Deal?" Brookings, December 2, 2013.https:/ / www.brookings.edu/onthe-record/why-did-ukraines-yanukovych-give-in-to-russian-pressure-on-eu-deal/

- $\quad$ Polityuk, Pavel, Zverev, Anton. 2017. "Why Ukrainian forces gave up Crimea without a fight - and NATO is alert." Reuters, July 24, 2017.http:/ / www.reuters.com/article/us-ukraine-crisis-crimea-

annexation/why-ukrainian-forces-gave-up-crimea-without-a-fight-and-nato-isalert-idUSKBN1A90G0

- Rand. 2017. Michael Kofman, Katya Migacheva, Brian Nichiporuk, Andrew Radin, Olesya Tkacheva, Jenny Oberholtzer "Lessons from Russia's Operations in Crimea and Eastern Ukraine." RAND Research Report, March 2017.https:/ / www.rand.org/pubs/research_reports/RR1498.html

- $\quad$ Reuters. 2014. "Russia entering "full-fledged economic crisis", says exminister Kudrin." Reuters, December 22, 2014.http:/ / www.reuters.com/article/russia-crisis/russia-entering-full-fledgedeconomic-crisis-says-ex-minister-kudrin-idUSL6N0U61L320141222

- Reuters. 2015. "Putin's defence fixation deepens Russian budget problems." Reuters, January 15, 2015.http://www.reuters.com/article/russiacrisis-budget/putins-defence-fixation-deepens-russian-budget-problemsidUSL6N0US25520150115

- $\quad$ RT. 2013. “Ukrainian police violently eject pro-EU protesters from Kiev square." RT, November 30, 2013.https://www.rt.com/news/ukraine-policedisperse-protest-509/

- $\quad$ RT. 2014. "Crimea declares independence, seeks UN recognition." RT, March 17, 2014.https://www.rt.com/news/crimea-referendum-results-official$250 /$

- RT. 2014 (2). “Obama authorizes 'economic embargo' on Russia's Crimea." RT, December 19, 2014.https://www.rt.com/usa/216143-obamasanctions-russia-crimea/

- Shevchenko, Vitaly. 2014. "Little green men" or "Russian invaders"?" BBC, March 11, 2014.

- $\quad$ Trach, Natalia. 2014. "Two EuroMaidan activists missing; foul play suspected." Kyiv Post, January 21, 2014.https://www.kyivpost.com/article/content/euromaidan/twoeuromaidan-activists-missing-foul-play-suspected-335343.html 
- $\quad$ Snegovaya, Maria. 2015. "Putin's information warfare in Ukraine. Soviet origins of Russia's hybrid warfare." Institute for the Study of War, September 2015.

- "Sputnik and Russia's New Theory of War." New York Times https:/ / www.nytimes.com/2017/09/12/us/politics/russia-facebookelection.html?hp\&action $=$ click\&pgtype $=$ Homepage\&clickSource $=$ storyheading\&module=second-column-region\&region=top-news\&WT.nav=top-news - $\quad$ Sputnik. 2014. "President Putin signs treaty to bring Crimea into Russia." Sputnik, March 18, 2014.https://sputniknews.com/voiceofrussia/news/2014_03_18/PresidentPutin-signs-treaty-of-joining-Crimea-Sevastopol-to-Russia-9079/

- $\quad$ Sutyagin, Igor. 2015. "Russian Forces in Ukraine”, RUSI papers, March 2015.https://www.rusi.org/downloads/assets/201503_BP_Russian_Forces_in_ Ukraine_FINAL.pdf

- The Telegraph. 2014. "Putin: 'Crimea has always been an integral part of Russia.'” The Telegraph, March 18, 2014.http:/ / www.telegraph.co.uk/news/worldnews/europe/ukraine/1070618 2/Putin-Crimea-has-always-been-an-integral-part-of-Russia.html

- Trenin, Dmitri. 2017. “Demands on Russian Foreign Policy And Its Drivers: Looking Out Five Years", Carnegie. http:/ / carnegie.ru/commentary/72799

- Union. 2014. “Одного из погибших сегодня застрелил снайпер, второго убили из пистолета Union”, January 22, 2014.

https:/ / www.unian.net/politics/875272-odnogo-iz-pogibshih-segodnyazastrelil-snayper-vtorogo-ubili-iz-pistoleta-vrachi.html

- $\quad$ US Army Europe. 2017. "Atlantic Resolve."

http:/ / www.eur.army.mil/ AtlanticResolve/

- Van Herpen, Marcel H. 2015. Putin's Wars. The Rise of Russia's New Imperialism, Rowman \& Littlefield Publishers: Lanham.

- White House. 2014. Executive Order -- Blocking Property of Certain

Persons Contributing to the Situation in Ukraine." White House, March 6, 2014. https://obamawhitehouse.archives.gov/the-pressoffice/2014/03/06/executive-order-blocking-property-certain-personscontributing-situation

- Wiener-Bronner, Danielle. 2014. "Referendum on Self-Rule in Ukraine 'Passes' with Over 90\% of the Vote." The Atlantic, May 12, 2014. 
https://www.theatlantic.com/international/archive/2014/05/referendum-onself-rule-in-ukraine-passes-with-over-90-of-the-vote/362062/

- Witte, Griff. 2014. "Finland feeling vulnerable amid Russian provocations." The Washington Post, November 23, 2014. https://www.washingtonpost.com/world/europe/finland-feeling-vulnerableamid-russian-provocations/2014/11/23/defc5a90-69b2-11e4-bafd6598192a448d_story.html?utm_term=.d0e5dfed03b6

\section{Bio}

Ryszard Machnikowski is the vice-dean for research and international affairs of the Faculty of International and Political Studies at the University of Lodz, Poland. He obtained M. Sc. in sociology (1991), Ph.D. in Social Sciences (1996), and D. Habilis in Social Sciences (2010), was a Soros FCO Scholar at Hertford College, Oxford University (1992-93), Fulbright Junior Scholar at Columbia University in the City of New York (1993-94); since 2011 associate professor at the Faculty of International and Political Studies, University of Lodz, Poland. In the years 2005 - 2009 the Head of the Center for Strategic Studies and Forecast at the Lodz School of International Studies, Poland. External Expert of National Forecast Program Poland 2020, expert at the Polish National Science Centre (NCN), Foreign Expert at the French CSFRS (Conseil Superieur de la Formation et de la Recherche Strategique), member of the Conseil Scientifique of M. Sc. Studies in criminology at the Conservatoire $\mathrm{N}$ ational des $\mathrm{A}$ rts et $\mathrm{M}$ étiers in Paris, expert and $\mathrm{M}$ ember of the A dvisory Board at the Countering Lone A ctor Terrorism(CLAT) network project coordinated by Institute for Strategic Dialogue in London (2015 - 16), consultant of the Police force in Lodz, including SWAT Team in the City of Lodz (SPAP Lodz). Specializes in terrorism and security studies, transatlantic relations, problems of globalization, author of three books and more than 50 scientific articles, chapters and reviews on these issues. 